\title{
Conserved bone microstructure in the shells of long-necked and short-necked chelid turtles (Testudinata, Pleurodira)
}

\author{
Torsten M. Scheyer \\ Paläontologisches Institut und Museum, Universität Zürich, Karl Schmid-Strasse 4, 8006 Zürich, Switzerland. \\ E-mail: tscheyer@pim.uzh.ch
}

\begin{abstract}
Received 23 May 2008

Accepted 7 August 2008

Published 20 February 2009

\section{Key Words}

Testudines

bone histology

long-necked Chelidae

short-necked Chelidae

Platychelys oberndorferi

Extant and fossil chelids are restricted to South America and Australasia. Based on morphological data, long-necked and short-necked chelids are hypothesised to form natural groups respectively, whereas molecular and serological data indicate South American and Australasian chelids are monophyletic, regardless of neck-length. Here I provide shell bone histological and microanatomical data and character mapping of seven chelid taxa and the Late Jurassic stem-pleurodiran Platychelys oberndorferi Wagner, 1853 to test both competing hypotheses. The chelid shells show conserved bone microstructures, many of which are plesiomorphic for all turtles. Part of the variation among chelid shell microstructures could be attributed to functional aspects associated with the ecology of the taxa, i.e. adaptation to an aquatic lifestyle. The character mapping further indicates that the hypothesis of clades based on neck length is supported by two synapomorphies (i.e., parallel-fibred bone grading into lamellar bone in internal cortex and vascularisation of internal cortex) and one less tree step (16 instead of 17) in contrast to the molecular-based separation based on geographic distribution.
\end{abstract}

\section{Introduction}

Pleurodira or side-necked turtles contain the three major crown clades Chelidae, Pelomedusidae and Podocnemidae, as well as the fossil clades Dortokidae, Platychelyidae, Euraxemydidae, Bothremydidae and Araripemydidae (Lapparent de Broin 2001; Danilov 2005; Gaffney et al. 2006). Whether Proterochersis robusta Fraas, 1913 lies within Pleurodira as sister taxon to all other pleurodirans (e.g. Gaffney et al. 2006), or outside of Testudines on the turtle stem (e.g. originally proposed by Rougier et al. 1995; Sukhanov 2006; Joyce 2007; Sterli 2008), is contested.

Today, Chelidae represents about 55/60 living species in 14/18 genera (lower numbers from Fritz \& Havaš 2007; higher numbers from Bickham et al. 2007), but the fossil record of Chelidae must still be considered to be poor (Gaffney et al. 2006). Both modern and fossil Chelidae are restricted to the South American continent and Australasia (Australia and New Guinea; Georges et al. 1998). Fossil chelids are unambiguously known from late Early and Late Cretaceous as well as the Palaeogene and Neogene strata of South America (Broin 1987; de la Fuente et al. 2001; Lapparent de Broin \& de la Fuente 2001; de la Fuente 2003) and from the Miocene and the
Eocene/?Palaeocene of Australia (Gaffney et al. 1989; Lapparent de Broin \& Molnar 2001). According to Joyce et al. (2004), Early Cretaceous turtle remains from South America may represent stem-group taxa of the Chelidae.

There is still an ongoing discussion about the interrelationships of chelid turtles (Fig. 1). In the classical and more recent morphological approaches (e.g. Boulenger 1888a; Burbidge et al. 1974; Gaffney 1977; Gaffney \& Meylan 1988; de la Fuente 2003; Bona \& de la Fuente 2005), two clades are recognised: (1) the long-necked genera of South America (i.e. Chelus, Hydromedusa) and Australasia (i.e. Chelodina) and (2) the South American and Australasian short-necked chelid genera (e.g. Phrynops, Platemys, Emydura). Gaffney et al. $(1989$, p. 7) pointed out that the "Emydura group is characterised almost entirely by features that are plesiomorphic for Chelidae". In contrast, phylogenetic analyses that are based on molecular and serological data support the hypothesis (even though the support is only weak in most cases) that the South American chelids on the one hand, and the Australasian chelid taxa on the other hand are more closely related to each other respectively, regardless of the neck lengths (Seddon et al. 1997; Shaffer et al. 1997; Georges et al. 1998; Fujita et al. 2004; Near et al. 2005; Krenz et al. 2005). 


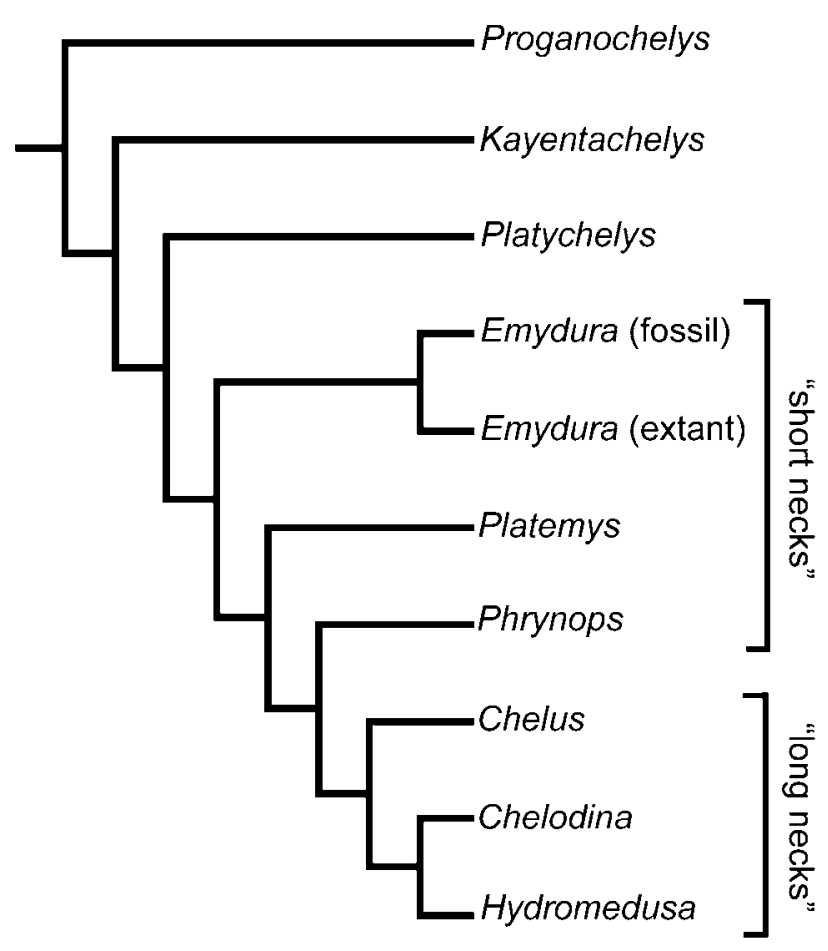

A

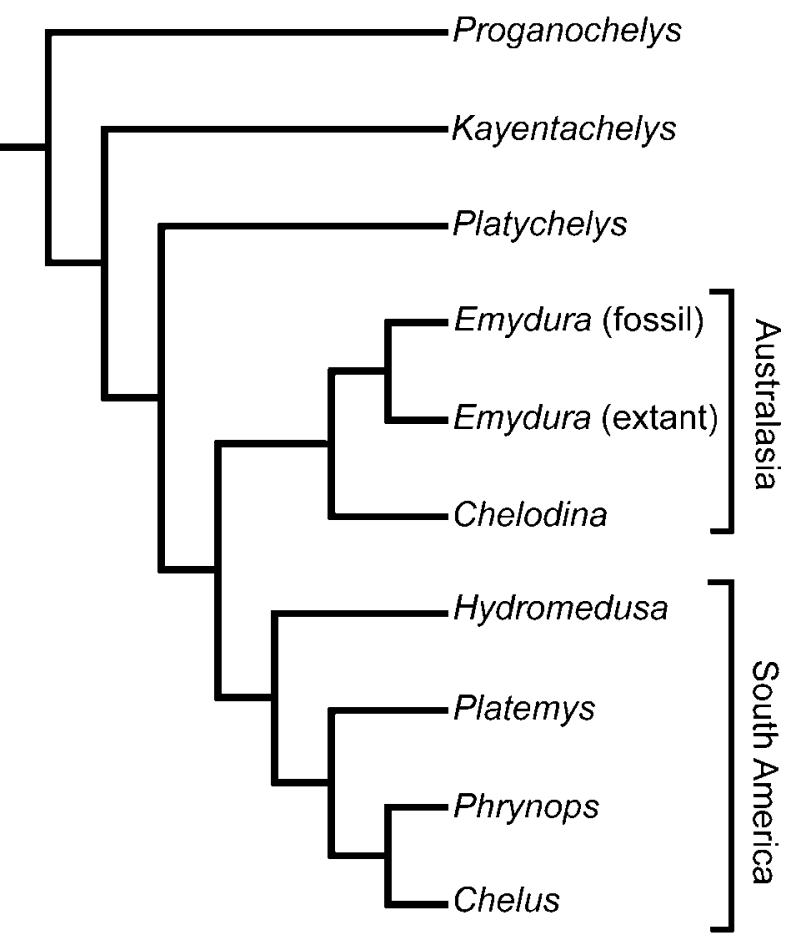

B

Figure 1. Competing phylogenetic hypotheses of the interrelationships of South American and Australasian Chelidae. In both hypotheses the two stem turtles Proganochelys quenstedti Baur, 1887 and Kayentachelys sp. and the stem pleurodire Platychelys oberndorferi Wagner, 1853 have been included as outgroups following Joyce (2007). A. Composite phylogeny favoured by most morphology-based analyses following mainly Gaffney (1977), Gaffney \& Meylan (1988) and Bona \& Fuente (2005). Brackets indicate the short-necked and long-necked chelid taxa. B. Phylogenetic hypothesis based on molecular data, adapted from the single most parsimonious tree based on mitochondrial 12S rRNA sequence data presented by Seddon et al. (1997, fig. 2). Brackets indicate the geographic distribution of the long-necked and short-necked chelid taxa. Although there are other well founded molecular/serologic-based analyses available (e.g. Georges et al. 1998; Fujita et al. 2004; Near et al. 2005; Krenz et al. 2005), these studies either lack the resolution or the taxa necessary for the character mapping presented herein.

The dimensions and shape of chelid shells are quite diverse ranging from small to large sizes and from smooth, unsculptured shells to strongly sculptured morphs carrying longitudinal ridges or knobs (e.g. the matamata). Similarly, the bone composition of the shell of chelids is highly variable, as exemplified by the high variation in the neural series from completely present to complete reduced (Pritchard 1988, 2008; Thomson $\&$ Georges 1996). The development of the pleurodiran shell was recently studied, including a series of the chelid Emydura subglobosa (Krefft, 1876). Results were found to be in overall accordance with data from Cryptodira and an alternative structural hypothesis for neural reduction is presented, based on heterochronic shift accompanied by restricted influence of epaxial musculature and dermal-epidermal interaction in bone formation (Scheyer et al. 2008).

Recently, the presence of phylogenetic signals in bone histological and microanatomical data was verified (e.g. Laurin et al. 2004; Cubo et al. 2005). The microstructure of turtle shell bones was found to be similarly influenced to various degrees by phylogenetic and functional influences and constraints (e.g. Scheyer \& Sander 2007; Scheyer \& Anquetin 2008). In the current study the question is thus addressed, whether the bone microstructures of the shell of chelid turtles can be used to test the competing phylogenies described above, or whether other, i.e., functional, aspects that work on the shell bone obscure any systematic value. Accordingly, the microstructures of the turtle shell bones of seven chelid taxa, including three extant long-necked species, three extant short-necked species and a fossil short-necked taxon are described. The palaeobiology of each taxon is briefly reviewed. Furthermore, to analyse how a stem-group pleurodiran taxon relates to the fossil and modern chelid genera, the Late Jurassic European taxon Platychelys oberndorferi Wagner, 1853 was sampled. With the addition of the two stem taxa Proganochelys quenstedti Baur, 1887 and Kayentachelys sp. (Scheyer 2007; Scheyer \& Sander 2007), the bone histological characters were then mapped on the two competing hypotheses of chelid relationships (Fig. 1).

\section{Material and methods}

The thin-sections were prepared and documented at the Institute of Palaeontology, University of Bonn, Germany. The sampling followed standard petrographic thin-sectioning procedures as described for example in Scheyer \& Sánchez-Villagra (2007). The description of the turtle shell elements follows Zangerl (1969), and the histological de- 
scriptions are mainly based on Francillon-Vieillot et al. (1990) and Scheyer \& Sánchez-Villagra (2007). If not specifically expressed, the plane of sectioning in costals is either anteroposteriorly (perpendicular to the progression of the ribs) or proximodistally oriented (parallel to the progression of the ribs), generally proximodistally oriented for peripherals and either anteroposteriorly or proximodistally oriented for plastral elements. Data on the samples used in this study were compiled into Table 1. For additional data on specimens refer to Scheyer (2007).

Due to the small sampling size, individual variation, ontogenetic variation, or variation based on sexual dimorphism cannot be ruled out; however, because significant changes in the bone histology seem to occur only on higher taxonomic levels, i.e. generic or family levels, they are not expected either (Scheyer \& Sánchez-Villagra 2007; Scheyer \& Sander 2007).

In the case of extant liquid-preserved (e.g. alcohol, formaldehyde) turtle specimens that are not macerated, the sampling was realised by core-drilling (e.g. Scheyer 2007; Scheyer \& Sánchez-Villagra 2007) and where applicable, the keratinous shield and dermal cover of the bones were left in place. Especially in larger specimens, it would be more sensible to sample the whole bone element to get a complete picture instead of a drilled core. However, the restricted sampling area of the drilling method parallels the situation in fragmentary fossils where the whole bone is not available for study.

Character mapping of the bone histological data was done using the software package Mesquite (Maddison \& Maddison 2004). Char-

Table 1. Material sectioned for the study including taxa names, accession numbers, element descriptions and general remarks.

\begin{tabular}{|c|c|c|c|}
\hline sampled taxa & specimen no. & sectioned shell elements & general remarks \\
\hline \multirow[t]{3}{*}{$\begin{array}{l}\text { Platychelys } \\
\text { oberndorferi }\end{array}$} & NMS 20076 & costal (costal3?) & $\begin{array}{l}\text { element complete with free rib end, strongly } \\
\text { sculptured with humps }\end{array}$ \\
\hline & NMS 20070 & peripheral (peripheral 5?) & $\begin{array}{l}\text { complete peripheral from bridge region, strongly } \\
\text { sculptured with humps }\end{array}$ \\
\hline & NMS 20076 & left hypoplastron & external bone surface with faint striation pattern \\
\hline \multirow[t]{2}{*}{$\begin{array}{l}\text { Emydura } \\
\text { subglobosa }\end{array}$} & ZFMK-58215 & left costal (costal 2?) & $\begin{array}{l}\text { sub-sampled as drilled bone core } \\
\text { (diameter } 12 \mathrm{~mm} \text { ) }\end{array}$ \\
\hline & ZFMK-58215 & left hyoplastron & $\begin{array}{l}\text { sub-sampled as drilled bone core } \\
\text { (diameter } 12 \mathrm{~mm} \text { ) }\end{array}$ \\
\hline \multirow[t]{4}{*}{ Emydura sp. } & UCMP V5762/57055 & costal fragment (max. $4 \mathrm{~mm}$ thick) & $\begin{array}{l}\text { scute sulci and shallow reticular grooves on } \\
\text { external bone surface }\end{array}$ \\
\hline & UCMP V5762/57055 & costal fragment (max. 9 mm thick) & $\begin{array}{l}\text { scute sulci and shallow reticular grooves on } \\
\text { external bone surface }\end{array}$ \\
\hline & UCMP V5762/57055 & peripheral & additional small pits on external bone surface \\
\hline & UCMP V5774/57270 & $\begin{array}{l}\text { hyo-/hypoplastron? } \\
\text { (max. } 12 \mathrm{~mm} \text { thick) }\end{array}$ & $\begin{array}{l}\text { scute sulci and shallow reticular grooves on } \\
\text { external bone surface }\end{array}$ \\
\hline \multirow[t]{2}{*}{$\begin{array}{l}\text { Chelodina } \\
\text { longicollis }\end{array}$} & ZMB 27258 & left costal (costal 2?) & $\begin{array}{l}\text { sub-sampled as drilled bone core } \\
\text { (diameter } 22 \mathrm{~mm} \text { ); shields still attached }\end{array}$ \\
\hline & ZMB 27258 & right hyoplastron & $\begin{array}{l}\text { sub-sampled as drilled bone core } \\
\text { (diameter } 22 \mathrm{~mm} \text { ); shields still attached }\end{array}$ \\
\hline \multirow[t]{2}{*}{$\begin{array}{l}\text { Platemys } \\
\text { platycephala }\end{array}$} & SMNS 10035 & $\begin{array}{l}\text { part of right costal } 2 \& \text { part of left } \\
\text { costal } 2 \text { (max. } 2 \mathrm{~mm} \text { thick) }\end{array}$ & $\begin{array}{l}\text { sub-sampled as drilled bone core (diameter } \\
22 \mathrm{~mm} \text { ); shields were already removed }\end{array}$ \\
\hline & SMNS 10035 & $\begin{array}{l}\text { proximal part of left hypo-plastron } \\
\text { (max. } 2 \mathrm{~mm} \text { thick) }\end{array}$ & $\begin{array}{l}\text { sub-sampled as drilled bone core (diameter } \\
12 \mathrm{~mm} \text { ); shields were already removed }\end{array}$ \\
\hline \multirow[t]{3}{*}{$\begin{array}{l}\text { Phrynops } \\
\text { geoffroanus }\end{array}$} & $\begin{array}{l}\text { YPM } 12611 \\
\text { YPM } 12611\end{array}$ & $\begin{array}{l}\text { neural } 3 \\
\text { costal } 3\end{array}$ & $\begin{array}{l}\text { whole macerated bone element was sampled } \\
\text { whole macerated bone element was sampled }\end{array}$ \\
\hline & YPM 12611 & peripheral 3 & whole macerated bone element was sampled \\
\hline & YPM 12611 & hyoplastron & whole macerated bone element was sampled \\
\hline \multirow[t]{2}{*}{$\begin{array}{l}\text { Hydromedusa } \\
\text { tectifera }\end{array}$} & ZFMK 51656 & left costal (costal 2?) & $\begin{array}{l}\text { sub-sampled as drilled bone core } \\
\text { (diameter } 22 \mathrm{~mm} \text { ); shields still attached }\end{array}$ \\
\hline & ZFMK 51656 & left hyoplastron & $\begin{array}{l}\text { sub-sampled as drilled bone core } \\
\text { (diameter } 22 \mathrm{~mm} \text { ); shields still attached }\end{array}$ \\
\hline \multirow[t]{3}{*}{ Chelus fimbriatus } & FMNH 269459 & costal (max. $6 \mathrm{~mm}$ thick) & $\begin{array}{l}\text { sub-sampled as drilled bone core } \\
\text { (diameter } 22 \mathrm{~mm} \text { ); bone stained green }\end{array}$ \\
\hline & FMNH 269459 & peripheral (max. $10 \mathrm{~mm}$ thick) & $\begin{array}{l}\text { sub-sampled as drilled bone core } \\
\text { (diameter } 22 \mathrm{~mm} \text { ); bone stained green }\end{array}$ \\
\hline & FMNH 269459 & hyoplastron (max. $4.5 \mathrm{~mm}$ thick) & $\begin{array}{l}\text { sub-sampled as drilled bone core } \\
\text { (diameter } 22 \mathrm{~mm} \text { ); bone stained green }\end{array}$ \\
\hline
\end{tabular}


acters were treated as 'unordered' and traced over the two composite hypotheses using 'parsimony ancestral state reconstruction'. The tree length was recorded for both phylogenies using the 'tree value using character matrix' option, and additional tree descriptions and apomorphy lists using both Acctran and Deltran optimisation were performed using PAUP 4.0beta10 (Swofford 2002).

Where appropriate, length and width measurements and maximum shell bone thicknesses are given for the sampled turtle shells, in which CCL stands for curved carapace length, CCW for curved carapace width, SPL for straight plastron length, and CPL for curved plastron length (see also Wyneken 2001).

Institutional Abbreviations. FMNH, The Field Museum, Chicago, Illinois, USA; IPB, Goldfuss-Museum, Institut für Paläontologie, Universität Bonn, Germany; SMNS, Staatliches Museum für Naturkunde, Stuttgart, Germany; NMS, Naturmuseum Solothurn, Switzerland; UCMP, Museum of Paleontology, University of California at Berkeley, California, USA; YPM, Peabody Museum of Natural History at Yale University, New Haven, Connecticut; USA; ZFMK, Zoologisches Forschungsinstitut und Museum Alexander Koenig, Bonn, Germany; ZMB, Zoologische Sammlung, Museum für Naturkunde, HumboldtUniversität zu Berlin, Germany.

Platychelys oberndorferi Wagner, 1853. According to Joyce (2007), P. oberndorferi is one of only three taxa that are currently hypothesised to unambiguously represent the stem-group of Pleurodira. P. oberndorferi was first described from lithographic limestone (Late Jurassic) near Kehlheim, southern Germany, but the taxon became much better known from Late Jurassic shallow marine limestones that were quarried near Solothurn, Switzerland (Bräm 1965). Fossil remains of P. oberndorferi are relatively scarce though. It is hypothesised to be a freshwater turtle that inhabited fluvial systems, swamps, and lakes of near-shore environments (Bräm 1965). Compared to the other turtle taxa from the Solothurn limestone (also known as the Solothurn 'turtle-limestone' or 'Schildkrötenkalk') that most probably lived in the near-shore marine environments, P. oberndorferi represents an allochthonous faunal element that was only occasionally brought into the marine limestone series. Typical for Platychelys oberndorferi are the humps and ridges of the shell that are also very clearly recognised in the thin-sections. As was recently presented by Scheyer \& Anquetin (2008), the material from the Guimarota coal mine (Bräm 1973), Portugal, originally assigned to aff. Platychelys sp. is a pleurosternid and not a platychelyid.

Short-necked Australasian Chelidae. Emydura subglobosa (Krefft, 1876) and fossil material of Emydura sp. were sampled. Today, all species of Emydura Bonaparte, 1836 are semi-aquatic and restricted to New Guinea and Australia (Iverson 1992; Ernst \& Barbour 1989) and there is no evidence for a more global distribution in the past. The carapace of extant Emydura spp. (CL lengths of up to $300 \mathrm{~mm}$ ) lack neurals so the costals meet medially above the vertebral column. A single neural was reported by Warren (1969) in a fossil specimen of Emydura sp. aff. E. macquari from Oligocene or Miocene deposits of Tasmania.

The extant specimen (ZFMK-58215) of E. subglobosa, preserved in liquid, had a CCL of $155 \mathrm{~mm}$, a CCW of $125 \mathrm{~mm}$, and a SPL of $130 \mathrm{~mm}$. The specimen was labelled E. albertisii Boulenger, 1888 in the collection (herein referred to as Boulenger 1888b), which is now considered to be a junior synonym of Emydura subglobosa (Krefft, 1876) by Iverson (1992) and Ernst \& Barbour (1989). The specimen is from New Guinea, but no further data concerning a locality is available. Generally, E. subglobosa dwells in rivers, lakes, and lagoons (e.g. Ernst \& Barbour 1989).

Four fossil shell elements of Emydura sp., collected in the Miocene Etadunna Formation of South Australia (Gaffney 1979, 1981), were sampled. As in other turtle groups, the taxonomy of chelids largely rests on cranial morphology and only to a lesser degree on shell morphology. Therefore, an assignment to one taxon or another will always be difficult without associated skull material. Although the sampled specimens are more or less fragmentary, comparison to best preserved fossil chelid shells UCMP 77348 and UCMP 72492 (Gaffney 1979) from the Miocene Wipajiri Formation (which is younger than the Etadunna Formation), lead to the tentative assignment to Emydura sp. in this case.

The internal surface of the bones is smooth, whereas the external bone surfaces carried sulci and a reticular vascularisation pattern. At least five small shallow pits of different depths are present on the external bone surface of the peripheral. It is apparent that these pits are not part of the sculpturing pattern. However, it is unclear if those pits appeared pre-mortem in the living animal, e.g. as the result of some kind of shell disease, or if they are diagenetic or decay structures.

Long-necked Australasian Chelidae. One liquid-preserved specimen of Chelodina longicollis (Shaw, 1794) was sampled. The species is known from eastern Australia (McCord \& Thomson 2002) where it inhabits low currency streams, swamps and lagoons (e.g. Ernst \& Barbour 1989). C. longicollis rarely basks outside the water, but it is known to travel overland to seek new water bodies in times of drought, or to even seek shelter on land for longer time periods (Legler \& Georges 1993; Greer 2006 and references therein). The thin neck can grow up to $60 \%$ of the total carapace length (Ernst \& Barbour 1989) and the species is known to adapt its skin-colour to the surrounding background by melanophore cell contraction and expansion (Woolley 1957). The sampled specimen (ZMB 27258) of C. longicollis has a CCL of $210 \mathrm{~mm}$, a CCW of $173 \mathrm{~mm}$, and a CPL of $178 \mathrm{~mm}$.

Short-necked South American Chelidae. Two short-necked species from South America, Platemys platycephala (Schneider, 1791) and Phrynops geoffroanus (Schweigger, 1812), were sampled. P. platycephala or extant twist-necked turtle (CL up to $180 \mathrm{~mm}$ ) lacks a neural series, and it is known to forage for longer time periods in the woods (e.g. Ernst \& Barbour 1989). In the sampled specimen of P. platycephala, the keratinous shields were already detached from the underlying dermis both from the carapacial and plastral side prior to sampling. The species does not occur as far south and southeast in South America as P. geoffroanus, a carnivorous species (CL up to about $350 \mathrm{~mm}$ ) that basks frequently and lives in a wide range of freshwater habitats with slow currents (e.g. Ernst \& Barbour 1989). The taxonomic status of Phrynops-group species is still under debate (McCord et al. 2001; Joyce et al. 2004; Bickham et al. 2007).

Long-necked South American Chelidae. Two long-necked species from South America, Hydromedusa tectifera Cope, 1870 and Chelus fimbriatus (Schneider, 1783), were sampled. H. tectifera is a rather inconspicuous turtle that prefers a snail diet (e.g. Pritchard 1979).

The specimen (ZFMK 51656) of H. tectifera comes from an area near Montevideo, Uruguay, but no further data is available. The liquid-preserved specimen had a CCL of $223 \mathrm{~mm}$, a CCW of $163 \mathrm{~mm}$, and a SPL of $155 \mathrm{~mm}$.

C. fimbriatus, the matamata, is one of the most bizarre turtles that alive today. It is found in many drainage systems of the northern part of South America where it prefers slow-moving habitats (e.g. Ernst \& Barbour 1989). The fringes at the flat triangular head and long neck, together with the brownish colour and the highly humped, keeled and serrated shell effectively help to dissolve the general shape of the turtle. This and a gape-and-suck feeding mechanism make the matamata an effective ambush predator (e.g. Pritchard 1979; Ernst \& Barbour 1989). Prior to its current storing in the FMNH collections, the extant specimen (FMNH 269459) of C. fimbriatus was stored in a tank with preservation liquid of unknown chemistry, which stained the shell bones and endoskeletal bones green. During sampling, the bonding dermal tissue between the keratinous shields and the underlying bone was found to be very strong in the carapace, whereas the keratinous shield was easily removed from the hyoplastron. In this taxon, the dermal and epidermal tissue between carapace bones and shields both fills and thus smoothes out topological differences or it amplifies the existing topology of the bone, leading to small humps in the shield cover. 


\section{Results}

The chelid turtle shells are described in a single section, because they all have similar histologies. Observed variation in the bone microstructures was generally closely related to differences in the outer morphology of the studied bone elements and is pointed out where applicable. Additional histological data on the taxa that exceed the scope of the present paper are found in Scheyer (2007) and Scheyer \& Sander (2007).

\section{Shell bone histology of Chelidae}

The sampled shell bones all show a diploe structure with external cortex (ECO) and internal cortex (ICO) framing an interior area of cancellous bone (CB). The ICO is reduced in thickness compared to the ECO in the samples of Emydura, Chelodina longicollis, and Chelus fimbriatus, whereas cortices of the shell bones of Platemys platycephala, Phrynops geoffroanus and Hydromedusa tectifera were of similar thickness. In anteroposteriorly sectioned costals, the ICO is usually thickest in the mid-part of the section (where the rib is incorporated) and slightly thinner towards the sutured margins of the bones. In the sampled costal of P. geoffroanus, a slight decrease in thickness of both ECO and ICO is observed from the proximal to the distal end of the bone. C. fimbriatus is the taxon with the strongest histological variation among the carapacial and plastral samples. But, again, this variation is strongly connected to the outer morphology of the elements. In all samples, bone cell lacunae lack canaliculi in the cortical bone layers.

External cortex. The ECO (Fig. 2A, B) consists of a compact bone tissue of interwoven structural fibre bundles (ISF). Fibre bundles of the ISF are of similar length and thickness and usually extend perpendicular, subparallel and diagonal to the surface of the bone, thus lending the bone tissue an even, regular appearance. In Emydura and P. platycephala, fibre bundles that insert perpendicular to the bone surface into the ECO are well observable, whereas these fibre bundles are more inconspicuous in other taxa. Generally, Sharpey's fibres are not well visible in the ECO. In C. fimbriatus, for example, Sharpey's fibres are present only in few of the humps and ridges of the ECO.

The bone tissue is vascularised by a mixture of scattered primary osteons, secondary osteons and primary vascular canals. The primary canals anastomose frequently and reticular patterns can be developed (Fig. 2A), usually with no apparent dominant orientation of the canals. In P. geoffroanus, however, horizontally arranged primary vascular canals appear to be more numerous compared to vertically arranged canals. The surface of the ECO is slightly rough, with primary osteons and canals opening up as small foramina on the surface of the bone. In P. platycephala, the ECO is mainly vascularised by primary osteons. In Emydura, only the external-most part of the ECO shows cyclical incremental Growth marks (GM). In other species, GM do occur but they are mostly too obscured to be countable.

Cancellous bone. The bone trabeculae are generally secondarily remodelled, but interstitial areas within the trabeculae are still composed of primary bone. The bone trabeculae are thus lined with secondary lamellar bone towards the bone cavities (Fig. 2C, D). Flattened and elongated bone cell lacunae follow the centripetally deposited lamellar bone linings, but rounder cell lacunae are clustered in the remnants of primary bone. In C.fimbriatus, the transition between the external and internal cortical layer and the interior $\mathrm{CB}$ is rather distinct instead of showing intermediate zones. In this species, the trabecular bone of the $\mathrm{CB}$ was largely primary with little secondary reconstruction.

The trabeculae in the CB are mostly short and thick in diameter and irregularly arranged. In P. platycephala, though, the trabeculae with dorsoventral orientation slightly dominate the $\mathrm{CB}$, thus leading to dorsoventrally elongated vascular cavities. In P. geoffroanus, vascular spaces and bone trabeculae are proximodistally elongated in the longitudinal section of the costal. In the thicker shell elements the larger vascular cavities are found in the more ventrally situated part of the CB. In fossil Emydura sp., the interior parts of the sampled peripheral express larger cavities through fusion of smaller vascular spaces. Here, the trabeculae may be longer and are thinner in diameter.

At the axillary/inguinal buttress region of the plastron sample of Emydura sp., the bone is further influenced by directed growth and remnants of former compact bone layers indicate earlier growth stages of this shell element. In the extant (core-drilled) samples, clumped and dried yellow-brown adipose tissue is present in the centres of the bone cavities.

Internal cortex. The ICO consists of parallel-fibred bone (Fig. 2E, F). In Emydura sp. and Emydura subglobosa, the parallel-fibred bone can locally grade into lamellar bone. Growth marks occur but they may not be as distinct as true lines of arrested growth. The bone tissue is avascular in C.longicollis and H. tectifera (Fig. 2E). In P. platycephala, scattered primary vascular canals pervade the ICO. In E. subglobosa, the ICO can be vascularised also by regularly scattered primary osteons, whereas erosion cavities lined with lamellar bone sometimes reach well into the ICO in the Emydura spp. (Fig. 2F).

In the fossil and extant samples of Emydura, the ICO was devoid of conspicuously angled fibre bundles, i.e. Sharpey's fibres. In the sub-sampled costal of $H$. tectifera, scattered Sharpey's fibres were found to insert the ICO in moderate to high angles. In C. fimbriatus, the 
ICO is well vascularised due to high amounts of primary osteons and canals, however the amounts of each were different between the carapace and plastron samples (evenly spaced primary osteons are much more common in the hyoplastron). Additionally, the parallelfibred bone of the ICO of C. fimbriatus locally shows more irregular fibrous arrangement that is similar in appearance to the ISF of the ECO.
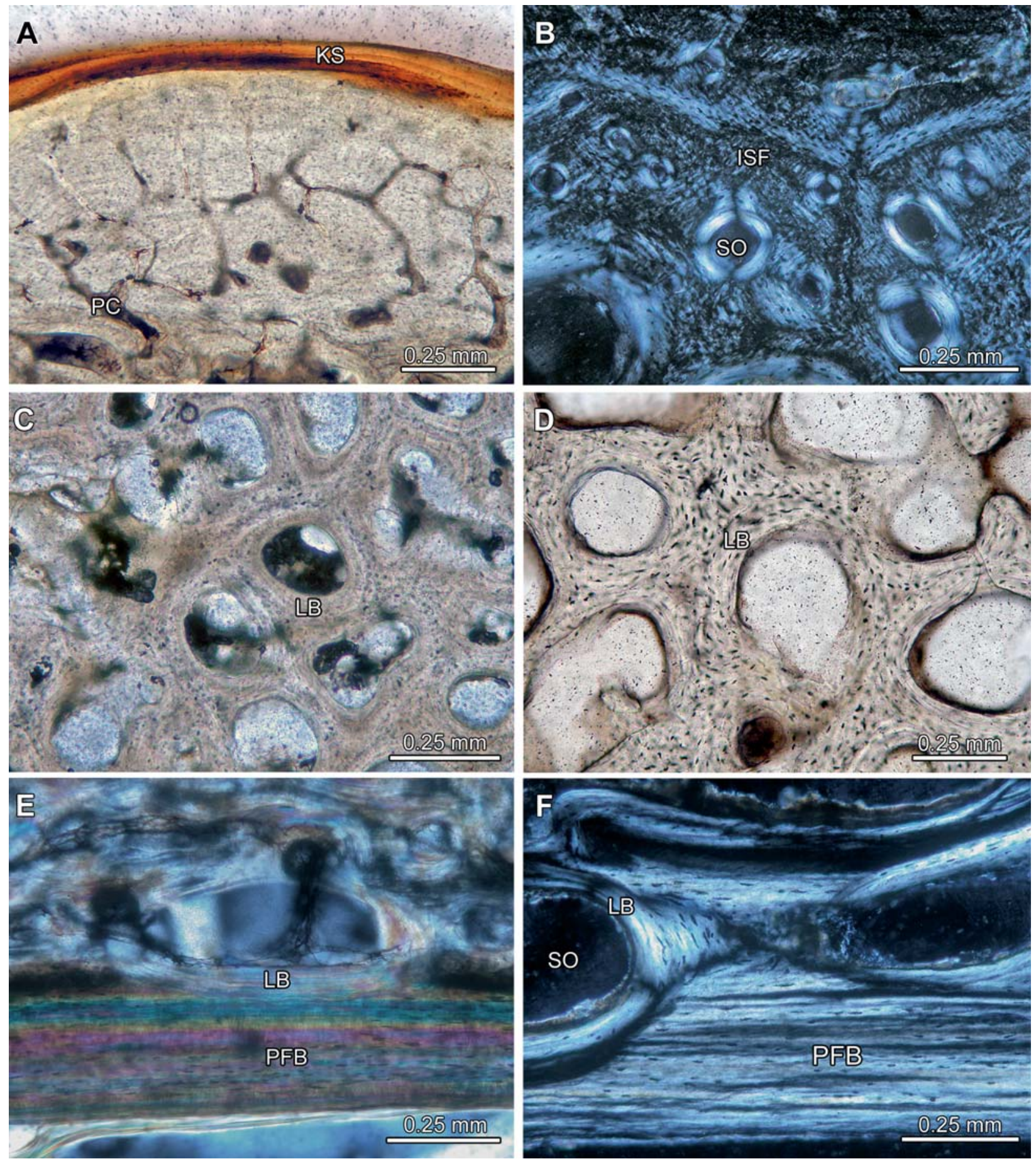

Figure 2. Bone histology of chelid turtles. Images $\mathbf{A}, \mathbf{C}$ and $\mathbf{D}$ are in normal transmitted light, images $\mathbf{B}, \mathbf{E}$ and $\mathbf{F}$ in polarised light. A. Close-up view of the external cortex and keratinous shield of costal of Chelodina longicollis. The cortical bone is vascularised by reticular primary vascular canals. B. Detail of the external cortex of costal of fossil Emydura sp. The bone tissue, which consists of interwoven structural fibre bundles, is vascularised by primary osteons and canals as well as scattered secondary osteons. C-D. Cancellous bone of hyoplastron of extant Emydura subglobosa (C) and of costal of fossil Emydura sp. (D). In both specimens, bone trabeculae are short and lined with secondary lamellar bone. E-F. Close-up views of the internal cortices and lower-most part of cancellous bone in the costals of Hydromedusa tectifera $(\mathbf{E})$ and fossil Emydura sp. (F). In both cases, the weakly vascularised cortical bone consists of parallel-fibred bone tissue. Secondary osteons and large erosion cavities are lined with secondary lamellar bone. Abbreviations: ISF - interwoven structural fibre bundles; KS - keratinous shield; LB - lamellar bone; PC - primary vascular canals; PFB - parallel-fibred bone; SO - secondary osteon. This figure is available in colour online at museum-fossilrecord.wiley-vch.de 
Sutures. The sutured margins (i.e. sampled in P. geoffroanus and P. platycephala) are composed of bone tissue similar to that found in the ECO. However, the bone tissue is dominated by long, horizontal fibre bundles, i.e., Sharpey's fibres, thus trending perpendicular to the lateral bone surface of the shell elements. The Sharpey's fibres gap the sutural spaces between the bones.

\section{Shell bone histology of Platychelys oberndorferi}

The carapacial fragments generally show thick external cortices and thinner internal cortices framing an interior part of cancellous bone, but the sampled hypoplastron had cortices of similar thickness.

External cortex. The ECO is composed of ISF, with the fibre bundles being fine and evenly distributed. Vascularisation of the external cortex is moderate with scattered primary osteons and primary vascular canals (Fig. 3A). Especially the primary osteons can occur as orderly aligned rows through the successive layers of the external cortex.

Cancellous bone. The $\mathrm{CB}$ is almost completely remodelled with only few areas where primary bone tissue is still preserved (Fig. 3A, B). The trabeculae are generally evenly distributed to form regular, similar sized, often rectangular shaped, bone cavities (Fig. 3B). Scattered secondary osteons may be present at the transition where the external cortex grades into the cancellous bone.

Internal cortex. The ICO consists of parallel-fibred bone (Fig. 3B), where coarser fibre bundles interdigitate with areas of finer fibre bundles. The direction of the fibre bundles is largely subparallel to the interior bone surface.

Variation. In the samples of $P$. oberndorferi, light variation in the bone microstructure is present but restricted to variation in thickness to the external cortex. In the costals and peripherals, the thickness of the external cortex is largely influenced by the occurrence of the characteristic humps of the shell bones. The interior cancellous bone can also be locally thickened in the region of the humps.

The free rib end of the sampled costal is sculptured into bony protrusions and emarginations instead of having a smooth bone surface (Fig. 3C).

\section{Character mapping}

The character mapping (Tab. 2; Fig. 4) indicates that most characters are distributed equally parsimoniously on both the morphological and the molecular/serological hypothesis. Only character \#1, the reduction of internal cortex in carapacial bones, shows three steps on the molecular tree instead of four steps on the morphological tree. In contrast, characters \#6 (parallel-fibred
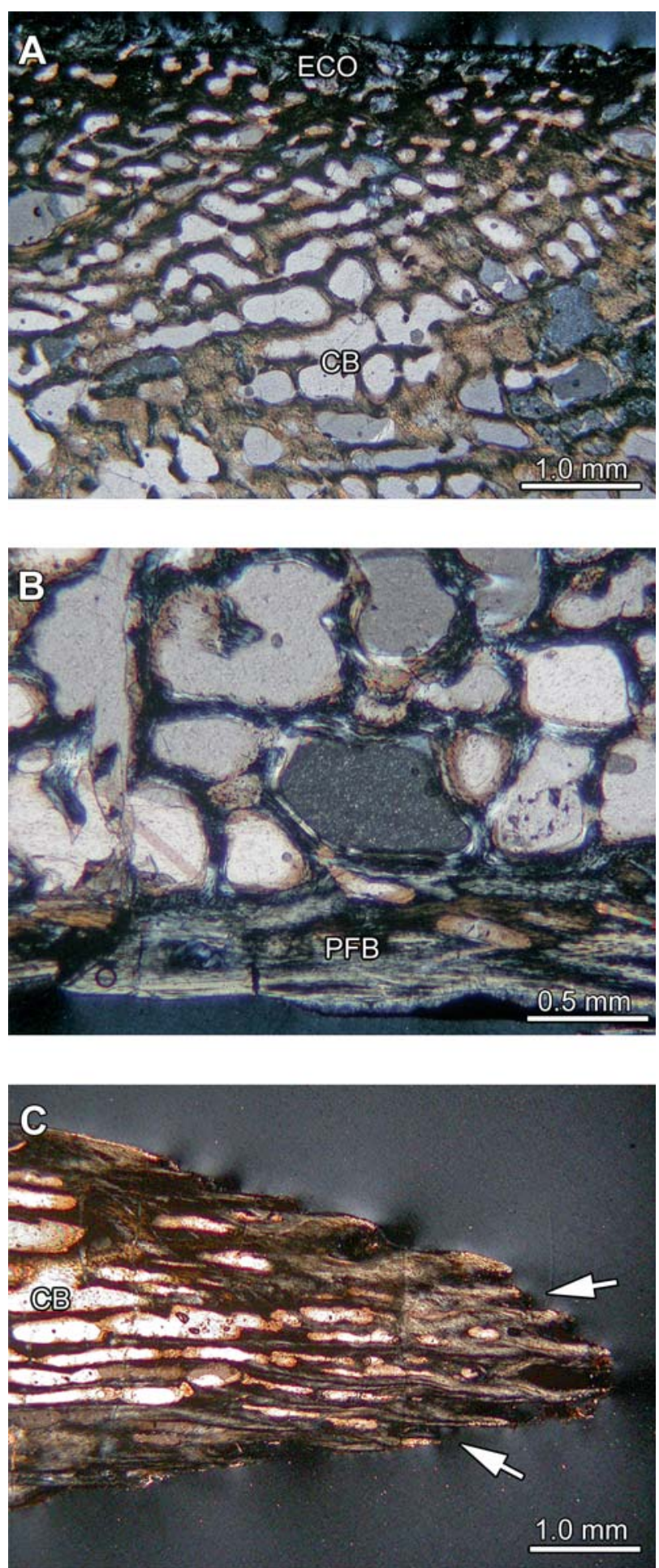

Figure 3. Bone histology of Platychelys oberndorferi. All images are in polarised light. A. Overview of the external cortex and large parts of the interior cancellous bone of the costal. B. Close-up view of the cancellous bone and the internal cortex. The vascular spaces of the cancellous bone can have rectangular shapes. The internal compact bone consists of parallel-fibred bone tissue. C. Free rib end that protrudes from the costal plate. Towards the costal plate proper (which lies outside of the image), cortical bone frames cancellous bone. Note bony pegs and emarginations at the lateral tip of the rib end (marked by arrows), which are reminiscent of the sutured margins of the shell bones. Abbreviations: CB - cancellous bone; ECO external cortex; PFB - parallel-fibred bone. This figure is available in colour online at museum-fossilrecord.wiley-vch.de 
Table 2. Matrix of seven bone histological characters (\#1-\#7), which were mapped on the conflicting morphological and molecular/serological hypotheses of Chelidae (Fig. 1). The basal taxa Proganochelys quenstedti and Kayentachelys sp. have been added as outgroups. The character values are given in parentheses. In the case of Phrynops geoffroanus, character \#3 was not clearly determinable. Character \#1 internal cortex in carapacial bones reduced in thickness compared to external cortex; \#2 internal cortex in plastral bones reduced in thickness compared to external cortex; \#3 fibre bundles that extend perpendicular to external bone surface prominent in external cortex; \#4 vascularisation of external cortex; \#5 reticular vascularisation patterns present in external cortex; \#6 parallel-fibred bone grading into lamellar bone in internal cortex; \#7 vascularisation of internal cortex.

\begin{tabular}{|c|c|c|c|c|c|c|c|}
\hline & $\# 1$ & \#2 & \#3 & \#4 & \#5 & \#6 & \#7 \\
\hline Proganochelys & no $(0)$ & no $(0)$ & no $(0)$ & low to absent $(0)$ & no $(0)$ & yes $(0)$ & low $(0)$ \\
\hline Kayentachelys & no $(0)$ & no $(0)$ & yes (1) & low to absent (0) & no $(0)$ & no (1) & low $(0)$ \\
\hline Platychelys & yes (1) & no $(0)$ & no $(0)$ & moderate to strong (1) & no $(0)$ & no (1) & moderate to strong (1) \\
\hline Emydura (fossil) & yes (1) & no $(0)$ & yes (1) & moderate to strong (1) & yes (1) & yes $(0)$ & moderate to strong (1) \\
\hline Emydura (extant) & yes (1) & yes (1) & yes (1) & moderate to strong (1) & yes (1) & yes $(0)$ & moderate to strong (1) \\
\hline Platemys & no $(0)$ & no $(0)$ & yes (1) & moderate to strong (1) & yes (1) & yes $(0)$ & moderate to strong (1) \\
\hline Phrynops & no $(0)$ & no $(0)$ & $?(?)$ & moderate to strong (1) & yes (1) & yes $(0)$ & moderate to strong (1) \\
\hline Chelus & yes (1) & no $(0)$ & no $(0)$ & moderate to strong (1) & yes (1) & no (1) & moderate to strong (1) \\
\hline Chelodina & yes (1) & yes (1) & no $(0)$ & moderate to strong (1) & yes (1) & no (1) & low (0) \\
\hline Hydromedusa & no $(0)$ & no $(0)$ & no $(0)$ & moderate to strong (1) & yes (1) & no (1) & low $(0)$ \\
\hline
\end{tabular}

bone grading into lamellar bone) and \#7 (vascularisation of internal cortex) needed only three instead of four and two instead of three steps on the morphological hypothesis, respectively. \#7 supported the sister-group relationship of Chelodina and Hydromedusa in the morphological tree under both Acctran and Deltran optimisation.
With the present taxon sampling, \#5 was recovered as a synapomorphy for Chelidae. The morphology-based tree had a tree length of 16 , a consistency index (CI) of 0.4375 and a rescaled consistency index $(\mathrm{RC})$ of 0.2188 , whereas the molecular-based tree had a tree length of 17 steps, a CI of 0.4118 and a RC of 0.1830.
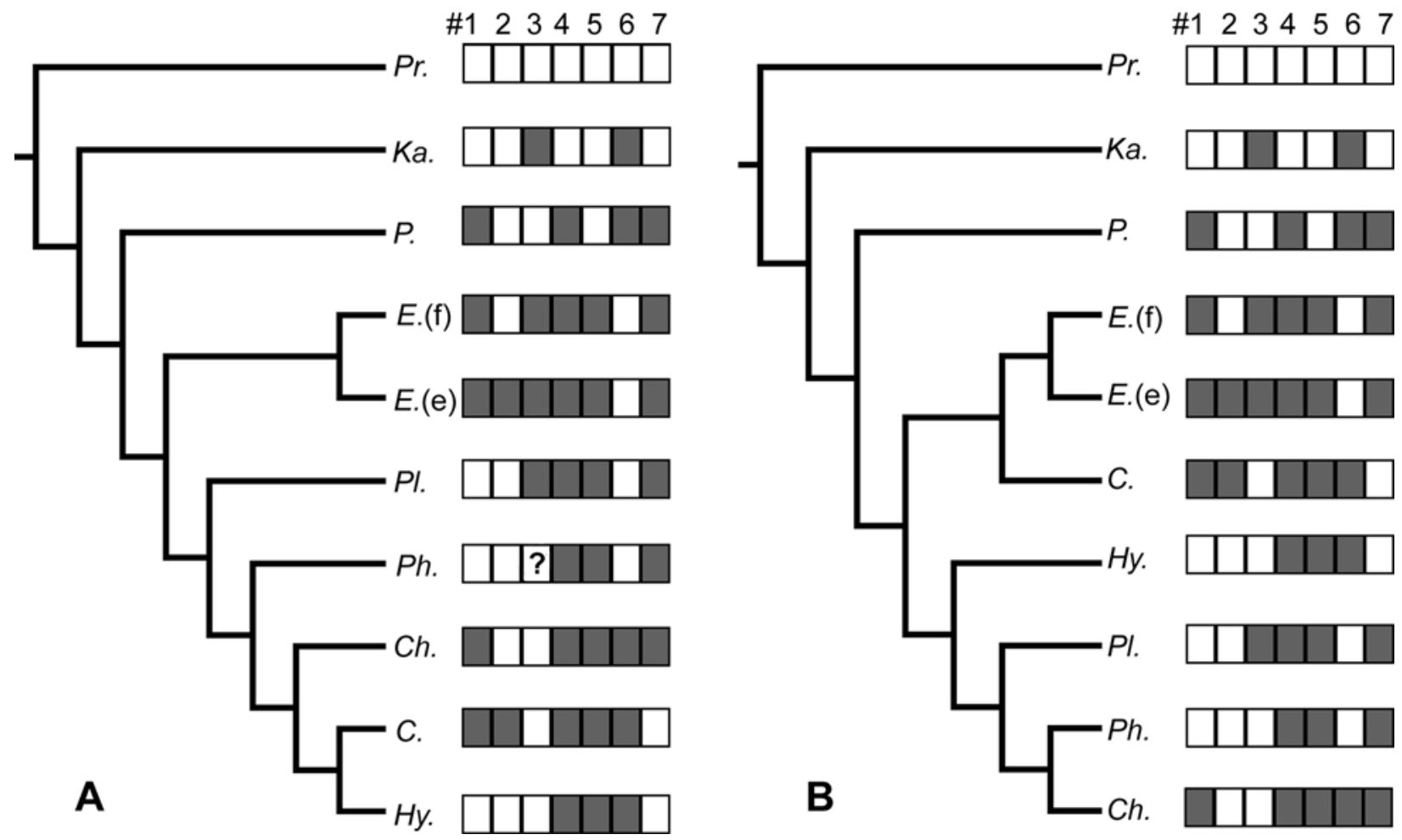

Figure 4. Distribution of character states (see Tab. 2) mapped on the competing morphology-based (A) and molecular/serologicalbased (B) phylogenies. See Figure 1 for information on phylogenies. Character state $=0$ is depicted as a white square; character state $=1$ as a gray square. In $\mathbf{A}$, character \#3 is scored with a question mark in Phrynops geoffroanus. Abbreviations: $\boldsymbol{C}$. - Chelodina longicollis; Ch. - Chelus fimbriatus; E.(e) - Emydura subglobosa (extant); E.(f) - Emydura sp. (fossil); Hy. - Hydromedusa tectifera; Ka. - Kayentachelys sp.; P. - Platychelys oberndorferi; Ph. - Phrynops geoffroanus; Pl. - Platemys platycephala; Pr. Proganochelys quenstedti. 


\section{Discussion}

As expressed by the results of the character mapping, neither the competing morphological nor the molecular/serological hypothesis is unambiguously well supported, arguing for a conserved condition of chelid shell bone structures. Only one step less is counted on the morphological than on the molecular hypothesis when histological characters are mapped.

Based on comparison with pelomedusoides taxa (Scheyer \& Sánchez-Villagra 2007), P. oberndorferi and with stem turtles (Scheyer \& Sander 2007), the diploe structure of the shell with external and internal compact bone framing interior cancellous bone, the metaplastic incorporation of dermal interwoven structural fibre bundles in the external cortex, the parallel-fibred bone of the internal cortex and the presence of Sharpey's fibres in chelid shells are plesiomorphic for all turtle shell bones (Scheyer 2007).

Whether the suture-like sculpturing of the free rib end in the costal of P. oberndorferi fulfils some functional aspect, i.e., to increase the bond between the costal with the rib socket in the peripheral is debatable.

Aside from the weak phylogenetic aspect revealed through the character mapping, observed variations among the chelid turtle shell bones could be partly related to other influences. Characters that were hypothesised to be functionally influenced (Scheyer \& Sander 2007), the reduction of bone tissue, the overall vascularisation of the shell elements, the increase in the organisation and ordered orientation of the bone trabeculae and vascular cavities in the cancellous bone, were also found within the chelid shell bones. Although a quantitative analysis of the bone microstructures has not been attempted yet, both the South American and the Australasian chelids thus fit into the category of semi-aquatic turtles which express low to moderate adaptation to aquatic freshwater habitats as proposed by Scheyer \& Sander (2007). None of the chelid taxa, on the other hand, show strong cortical bone reduction as occurs, for example, in marine turtles.

The fossil Emydura sp. is regarded as being moderately adapted to the aquatic environment, similar to its extant relative E. subglobosa. Connections to a more semi-aquatic versus a fully aquatic live style remain speculative for the fossil Emydura, based only on the bone histological evidence of its shell. Few chelid turtles thus seem to reach the grade of order in trabecular arrangement and overall bone vascularisation as the stem pleurodiran P. oberndorferi, which shows moderate adaptation to the aquatic environment (see also Scheyer \& Sander 2007).

\section{Conclusions}

Although the fossil record of chelid turtles reaches back into the Mesozoic, presumably providing enough time for potential phylogeny-induced variation to accu- mulate in the shell bones, the shell bone microstructure only slightly supports the morphology-based hypothesis in which the short necked and the long necked chelids form natural groups respectively. On the other hand, if functional aspects are working on the bone microstructures in chelids, this can be used to assess the palaeoecology of fossil taxa. Future work may further elucidate whether and how the biology, habitat preference, and behaviour of the turtle species respectively influence shell bone microstructures.

\section{Acknowledgements}

The author likes to thank J. H. Hutchison and P. A. Holroyd, UCMP, W. G. Joyce and G. Watkins-Colwell, YPM, R. Günther and colleagues, MfN Berlin, A. Resetar and colleagues, FMNH, E. Müller, NMS, W. Böhme, ZFMK, and A. Schlüter and colleagues, SMNS, for providing samples for histological sectioning. I thank M. Sander, IPB, for his supervision and support. W. Joyce, YPM, and N. Klein, IPB, are thanked for all discussions concerning turtles; O. Dülfer, R. Redelstorff, and D. Wolff, IPB, for their various helps in preparing thinsections. D. Kranz and G. Oleschinski, IPB are acknowledged for their various technical supports. This research was supported by DFG funding, grant \#SA 469/15-1 and the Doris and Samuel P. Welles Fund (UCMP). W. G. Joyce, J. Sterli and one anonymous reviewer are thanked for their constructive comments on an earlier version of the manuscript.

\section{References}

Baur, G. 1887. Ueber den Ursprung der Extremitäten der Ichthyopterygia. - Berichte über die Versammlungen des Oberrheinischen Geologischen Vereines 20: 17-20.

Bickham, J. W., Iverson, J. B., Parham, J. F., Philippen, H.-D., Rhodin, A. G. J., Shaffer, B. S., Spinks, P. Q. \& Van Dijk, P. P. 2007. An annotated list of modern turtle terminal taxa with comments on areas of taxonomic instability and recent change. - Chelonian Conservation and Biology Research Monographs 4: 173-199.

Bona, P. \& de la Fuente, M. S. 2005. Phylogenetic and paleobiogeographic implications of Yaminuechelys maior (Staesche, 1929) new comb., a large long-necked chelid turtle from the early Paleocene of Patagonia, Argentina. - Journal of Vertebrate Paleontology 25 (3): 569-582.

Bonaparte, C. L. 1836. Cheloniorum Tabula Analytica. Romae.

Boulenger, G. A. 1888a. On the characters of the chelonian families Pelomedusidae and Chelydidae. - Annual Magazine of Natural History, Series 61: 346-347.

Boulenger, G. A. 1888b. On the chelydoid chelonians of New Guinea. - Annali del Museo Civico di Storia Naturale di Genova (2. Ser.) 6: 449-452.

Bräm, H. 1965. Die Schildkröten aus dem oberen Jura (Malm) der Gegend von Solothurn. - Schweizerische Paläontologische Abhandlungen 83: 1-190.

Bräm, H. 1973. Chelonia from the Upper Jurassic of Guimarota mine (Portugal). Contribuição para o conhecimento da fauna do Kimeridgiano da Mina de Lignito Guimarota (Leiria, Portugal) III Parte, VII. - Memorias dos Serviços geológicos de Portugal, (nova Sér.) 22: 135-141.

Broin, F. de. 1987. The late Cretaceous fauna of Los Alamitos, Patagonia, Argentina. Part IV. Chelonia. - Revista del Museo Argentino de Ciencias Naturales, Bernardino Rivadavia, Paleontologia 3 (3): 131-139. 
Burbidge, A. A., Kirsch, J. A. W. \& Main, A. R. 1974. Relationships within the Chelidae (Testudines: Pleurodira) of Australia and New Guinea. - Copeia 1974 (2): 392-409.

Cope, E. D. 1870. Seventh contribution to the herpetology of tropical America. - Proceedings of the American Philosophical Society 11 (81): 147-169.

Cubo J., Ponton, F., Laurin, M., Margerie, E. de \& Castanet, J. 2005. Phylogenetic signal in bone microstructure of sauropsids. - Systematic Biology 54 (4): 562-574.

Danilov, I. G. 2005. Die fossilen Schildkröten Europas. In Fritz, U. (ed.). Handbuch der Reptilien und Amphibien Europas. Band 3/ IIIB: Schildkröten (Testudines) II. Aula-Verlag, Wiebelsheim: pp. 329-441.

Ernst, C. H. \& Barbour, R. W. 1989. Turtles of the World. Smithonian Institution Press, Washington D.C.

Fraas, E. 1913. Proterochersis, eine pleurodire Schildkröte aus dem Keuper. - Jahreshefte des Vereins für vaterländische Naturkunde in Württemberg 80: 1-30.

Francillon-Vieillot, H., Buffrénil, V. de, Castanet, J., Géraudie, J., Meunier, F. J., Sire, J. Y., Zylberberg, L. \& Ricqlès, A. de. 1990. Microstructure and mineralization of vertebrate skeletal tissues. In Carter, J. G. (ed.). Skeletal Biomineralization: Patterns, Processes and Evolutionary Trends. Van Nostrand Reinhold, New York: pp. 471-530.

Fritz, U. \& Havaš, P. 2007. Checklist of chelonians of the world. Vertebrate Zoology 57 (2): 149-368.

de la Fuente, M. S. 2003. Two new pleurodiran turtles from the Portezuelo Formation (Upper Cretaceous) of Northern Patagonia, Argentina. - Journal of Paleontology 77 (3): 559-575.

de la Fuente, M. S., Lapparent de Broin, F. de \& Manera de Bianco, T. 2001. The oldest and first nearly complete skeleton of a chelid, of the Hydromedusa sub-group (Chelidae, Pleurodira), from the Upper Cretaceous of Patagonia. - Bulletin de la Société Géologique de France 2: 237-244.

Fujita, M. K., Engstrom, T. N., Starkey, D. E. \& Shaffer, B. S. 2004 Turtle phylogeny: insights from a novel nuclear intron. - Molecular Phylogenetics and Evolution 31: 1031-1040.

Gaffney, E. S. 1977. The side-necked turtle family Chelidae: a theory of relationships using shared derived characters. - American Museum Novitates 2620: 1-28.

Gaffney, E. S. 1979. Fossil chelid turtles of Australia. - American Museum Novitates 2681: 1-23.

Gaffney, E. S. 1981. A review of the fossil turtles of Australia. American Museum Novitates 2720: 1-38.

Gaffney, E. S. \& Meylan, P. A. 1988. A phylogeny of turtles. In Benton, M. J. (ed.). The Phylogeny and Classification of the Tetrapods. Volume 1: Amphibians, Reptiles, Birds. Clarendon Press, Oxford: pp. 157-219.

Gaffney, E. S., Archer, M. \& White, A. 1989. Chelid turtles from the Miocene freshwater limestones of Riversleigh Station, Northwestern Queensland, Australia. - American Museum Novitates 2959: 1-10.

Gaffney, E. S., Tong, H. \& Meylan, P. A. 2006. Evolution of the sidenecked turtles: the families Bothremydidae, Euraxemydidae, and Araripemydidae. - Bulletin of the American Museum of Natural History 300: 1-698.

Georges, A., Birrell, J., Saint, K. M., McCord, W. \& Donnellan, S. C. 1998. A phylogeny for side-necked turtles (Chelonia: Pleurodira) based on mitochondrial and nuclear gene sequence variation. Biological Journal of the Linnean Society 67: 213-246.

Greer, A. E. 2006. Chelidae. Encyclopedia of Australian Reptiles. Australian Museum Online. http://www.amonline.net.au/herpetology/research/encyclopedia.pdf; Version date: 7 August 2006.

Iverson, J. B. 1992. A Revised Checklist with Distribution Maps of the Turtles of the World. Privately published, Richmond, IN.

Joyce, W. G. 2007. Phylogenetic relationships of Mesozoic turtles. Bulletin of the Peabody Museum of Natural History 48 (1): $3-$ 102.
Joyce, W. G., Parham, J. F. \& Gauthier, J. A. 2004. Developing a protocol for the conversion of rank-based taxon names to phylogenetically defined clade names, as exemplified by turtles. - Journal of Paleontology 78 (5): 989-1013.

Krefft, G. 1876. Notes on Australian animals in New Guinea with description of a new species of fresh water tortoise belonging to the genus Euchelymys (Gray). - Annali del Museo Civico di Storia Naturale di Genova 8: 390-394.

Krenz, J. G., Naylor, G. J. P., Shaffer, B. S. \& Janzen, F. J. 2005. Molecular phylogenetics and evolution of turtles. - Molecular Phylogenetics and Evolution 37: 178-191.

Lapparent de Broin, F. de. 2001. The European turtle fauna from the Triassic to the Present. - Dumerilia 4 (3): 155-217.

Lapparent de Broin, F. de \& Molnar, R. E. 2001. Eocene chelid turtles from Redbank Plains, Southeast Queensland, Australia. - Geodiversitas 23 (1): 41-79.

Lapparent de Broin, F. de \& Fuente, M. S. de la. 2001. Oldest world Chelidae (Chelonii, Pleurodira), from the Cretaceous of Patagonia, Argentina. - Comptes Rendues de l'Académie des Sciences Paris, Sciences de la Terre et des Planètes / Earth and Planetary Sciences 333: 463-470.

Laurin, M., Girondot, M. \& Loth, M.-M. 2004. The evolution of long bone microstructure and lifestyle in lissamphibians. - Paleobiology 30 (4): 589-613.

Legler, J. M. \& Georges, A. 1993. Family Chelidae. In Glasby, C. G., Ross, G. J. B. \& Beesley, P. L. (eds). Fauna of Australia 2A-Amphibia and Reptilia. Australian Government Publishing Service. http://www.environment.gov.au/biodiversity/abrs/publications/fauna-of-australia/fauna-2a.html.

Maddison, W. P. \& Maddison, D. R. 2004. Mesquite: a modular system for evolutionary analysis. Version 1.05. http://mesquiteproject.org.

McCord, W. P., Joseph-Ouni, M. \& Lamar, W. W. 2001. Taxonomic reevaluation of Phrynops (Testudines: Chelidae) with the description of two new genera and a new species of Batrachemys. - Revista de Biología Tropical 49 (2): 1-57.

McCord, W. P. \& Thomson, S. A. 2002. A new species of Chelodina (Testudines: Pleurodira: Chelidae) from Northern Australia. Journal of Herpetology 36 (2): 255-267.

Near, T. J., Meylan, P. A. \& Shaffer, B. S. 2005. Assessing concordance of fossil calibration points in molecular clock studies: an example using turtles. - American Naturalist 165 (2): 137-146.

Pritchard, P. C. H. 1979. Encyclopedia of Turtles. T. F. H. Publications, Neptune, New Jersey.

Pritchard, P. C. H. 1988. A survey of neural bone variation among recent chelonian species, with functional interpretations. - Acta Zoologica Cracoviensia 31 (26): 625-686.

Pritchard, P. C. H. 2008. Evolution and structure of the turtle shell. In Wyneken, J., Godfrey, M. H. \& Bels, V. (eds). Biology of Turtles. CRC Press, Boca Raton: pp. 45-83.

Rougier, G. W., de la Fuente, M. S. \& Arcucci, A. B. 1995. Late Triassic turtles from South America. - Science 268 (5212): 855858.

Scheyer, T. M. 2007. Comparative bone histology of the turtle shell (carapace and plastron): implications for turtle systematics, functional morphology, and turtle origins. PhD Thesis, MathematischNaturwissenschaftliche Fakultät, University of Bonn. pp. 343 [URN: http://nbn-resolving.de/urn:nbn:de:hbz:5N-12299; URL http://hss.ulb.uni-bonn.de/diss_online/math_nat_fak/2007/scheyer_torsten].

Scheyer, T. M. \& Anquetin, J. 2008. Bone histology of the Middle Jurassic turtle shell remains from Kirtlington, Oxfordshire, England. - Lethaia 41 (1): 85-96.

Scheyer, T. M. \& Sánchez-Villagra, M. R. 2007. Carapace bone histology in the giant pleurodiran turtle Stupendemys geographicus: phylogeny and function. - Acta Palaeontologica Polonica 52 (1): $137-154$ 
Scheyer, T. M. \& Sander, P. M. 2007. Terrestrial palaeoecology for basal turtles indicated by shell bone histology. - Proceedings of the Royal Society of London B 274 (1620): 1885-1893.

Scheyer, T. M., Brüllmann, B. \& Sánchez-Villagra, M. R. 2008. The ontogeny of the shell in side-necked turtles, with emphasis on the homologies of costal and neural bones. - Journal of Morphology 269 (8): 1008-1021. [DOI: 10.1002/jmor.10637].

Schneider, J. G. 1783. Allgemeine Naturgeschichte der Schildkröten, nebst einem systematischen Verzeichnisse der einzelnen Arten und zwey Kupfern. Johann Gotfried Müllersche Buchhandlung, Leipzig.

Schneider, J. G. 1791. Beschreibung und Abbildung einer neuen Art von Wasserschildkröte nebst Bestimmungen einiger bisher wenig bekannten fremden Arten. - Schriften der Gesellschaft naturforschender Freunde zu Berlin 10 (3): 259-284.

Schweigger, A. F. 1812. Prodromus monographiae Cheloniorum, Pt. 1. - Königsberger Archiv für Naturwissenschaft und Mathematik 1812: 271-458.

Seddon, J. M., Georges, A., Baverstock, P. R. \& McCord, W. 1997. Phylogenetic relationships of chelid turtles (Pleurodira: Chelidae) based on mitochondrial 12S rRNA gene sequence variation. Molecular Phylogenetics and Evolution 7 (1): 55-61.

Shaffer, H. B., Meylan, P. \& McKnight, M. L. 1997. Tests of turtle phylogeny: molecular, morphological, and paleontological approaches. - Systematic Biology 46: 234-268.

Shaw, G. 1794. Zoology of New Holland. Sowerby, London.
Sterli, J. 2008. A new, nearly complete stem turtle from the Jurassic of South America with implications for turtle evolution. - Biology Letters 4 (3): 286-289.

Sukhanov, V. B. 2006. An archaic turtle, Heckerochelys romani gen. et sp. nov., from the Middle Jurassic of Moscow region, Russia. Fossil Turtle Research, Vol. 1, Russian Journal of Herpetology 13 (Supplement): 112-118.

Swofford, D. L. 2002. PAUP*. Phylogenetic Analysis Using Parsimony (* and Other Methods). Version 4. Sinauer Associates, Sunderland, Massachusetts. http://paup.csit.fsu.edu.

Thomson, S. \& Georges, A. 1996. Neural bones in Australian chelid turtles. - Chelonian Conservation and Biology 2 (1): 82-86.

Wagner, A. 1853. Beschreibung einer fossilen Schildkröte und etlicher anderer Reptilien-Überreste aus den lithographischen Schiefern und dem grünen Sandstein von Kehlheim. - Abhandlungen der mathematisch-physischen Classe der Königlich-Bayerischen Akademie der Wissenschaften 7 (1): 239-264.

Warren, J. W. 1969. Chelid turtles from the mid-Tertiary of Tasmania. - Journal of Paleontology 43 (1): 179-182.

Woolley, P. 1957. Colour change in a chelonian. - Nature 179 (4572): $1255-1256$.

Wyneken, J. 2001. The anatomy of sea turtles. - National Oceanic and Atmospheric Administration (NOAA) Technical Memorandum NMFS-Southeast Fisheries Science Center (SEFSC) 470: 1-172.

Zangerl, R. 1969. The turtle shell. In Gans, C., Bellairs, A. d'A. \& Parsons, T. S. (eds). Biology of the Reptilia. Vol. 1 Morphology A. Academic Press, London: pp. 311-339. 